Article

\title{
University Community Partnerships
}

\section{Jonathan G. Cooper ${ }^{1}$, Zeenat Kotval-K ${ }^{2}$, Zenia Kotval ${ }^{2, *}$ and John Mullin ${ }^{1}$}

1 Department of Landscape Architecture and Regional Planning, University of Massachusetts Amherst, 111 Thatcher Road, Amherst, MA 01003, USA; E-Mails: jgcooper@larp.umass.edu (J.C.); jmullin@provost.umass.edu (J.M.)

2 School of Planning, Design and Construction, Michigan State University, 552 W. Circle Drive, East Lansing, MI 48824, USA; E-Mail: kotvalze@msu.edu

* Author to whom correspondence should be addressed; E-Mail: kotval@msu.edu; Tel.: +1-517-353-9362.

Received: 12 December 2013; in revised form: 14 February 2014 / Accepted: 3 March 2014 / Published: 11 March 2014

\begin{abstract}
University-Community Partnerships have been recognized as a valuable contribution to both the academic community and our cities and towns. In the words of Henry Cisneros, former U.S. Department of Housing and Urban Design secretary, "The long-term futures of both the city and the university in this country are so intertwined that one cannot—or perhaps will not—survive without the other.” Increasingly, colleges and university are bringing their time, energy and resources to bear on local problems. They are using their other physical, financial and intellectual capital to facilitate economic development, provide social services, technical assistance and create opportunities for applied research.
\end{abstract}

Keywords: University-community partnerships; town-gown relationships; New England region

\section{Introduction}

In 1994, the US Department of Housing and Urban Development established the Office of University Partnerships (OUP), creating grant initiatives to expand the number of partnerships between universities and the communities that host them. Then-Secretary Henry Cisneros published "The University and the Urban Challenge” one year later, identifying universities as major generators of 
jobs and tax revenue, as well as potential engines of urban revitalization [1]. Four factors contributed to this watershed moment of federal activity: the growth of universities since the end of World War II; the sustained decline of manufacturing and other urban-centered industry sectors in roughly the same time span; the economic and demographic shifts to city life concomitant with that decline; and the increasing visibility of public-private partnerships in local and regional undertakings.

In its first year, the OUP distributed \$9.8 million to eighteen institutions in ten states across the country to support the creation of Community Outreach Partnership Centers (COPC). The OUP continued to award grants on an annual basis through 2011, via the COPC program and a number of additional programs [2]. In that time, many partnerships between universities and communities were formed without OUP assistance as well, underscoring the cultural shift the OUP was created to encourage. The breadth of these partnerships is considerable, a result of both the variety of colleges and universities involved, and the multifaceted needs of the communities that host them. However, whether public or private, community college or Association of American Universities (AAU) member, land grant university or liberal arts college, each of these institutions is a landowner exempt from property taxation. For municipalities with an extensive university presence, this can create an imbalance between the overall benefit to the wider public provided by the university, and the loss of tax revenue borne solely by the municipality ([3], p. 2).

This paper focuses on university-community partnerships in municipalities with a number of common challenges: an exceptionally high percentage of tax-exempt properties on their rolls; a long and often tense relationship with the institutions of higher education they are home to; physical constraints on real estate development; a formerly robust manufacturing presence long on the decline; and considerable reliance on universities to provide jobs and economic activity. While a number of older cities throughout the country fit this description, it is unsurprising that these case studies are all found in southern New England, where the density of settlement is high, the level of deindustrialization is extensive, and the influence of the university in municipal and community affairs is powerful. Boston, Worcester, Providence, and New Haven, the cities included in this paper, are home to a total of more than fifty colleges and universities. Taken together, those fifty-plus institutions represent a considerable portion of the total employment, acreage, and economic impact within the cities' borders.

To select from the several dozen universities in these cities, the authors applied three filters: private institutions only, to highlight public-private problem solving; partnership initiatives undertaken without OUP grants, to demonstrate university-community creativity and initiative; and an institutional diversity, to broaden the relevance of the case studies to universities of all sizes and statures. In addition to these filters the case studies stress the importance of considering the role of third-parties/intermediaries in university-community partnership. As Maurrasse [4] describes, partnerships are often "messy"; partnerships do not always select the right problems to address; and existing societal power dynamics continue to play out in partnerships. As such, strong non-profits or other third parties intermediaries can introduce a community context not always apparent to partners. The universities chosen (Northeastern, Yale, Johnson and Wales, and Worcester Polytechnic Institute (WPI)) vary considerably by a number of measurements. Enrollments range from 5900 at WPI to 24,500 at Northeastern. Endowments range from \$240 million at Johnson and Wales to \$19.3 billion at Yale [5]. Lastly, the four universities occupy distinct niches in the spectrum of higher education 
institutions: one career-oriented university with a largely regional draw (Johnson and Wales); one applied science and technology-focused university of high regard (WPI); one arts and sciences university committed to increasing its national prominence (Northeastern); and one globally pre-eminent research university of exceptional stature (Yale).

What follows are examples of university-community partnerships that took advantage of opportunities to bring university uses and community uses into the same space, whether residential, commercial, educational, natural, or social. Of special import is the tripartite nature of the partnerships: in each case, a third party beyond the university and the municipality is essential to the partnership's success. As is the case in every university-community partnership, there is no "blank slate." Therefore, particular attention has been paid to describing the town-gown context in which the partnership operates.

\section{Boston: Northeastern and Davenport Commons}

The initial designs for what became Northeastern University’s Davenport Commons proposed an integrated dormitory space located near the campus in the Roxbury neighborhood of Boston. The Davenport Commons was designed for 879 students with 1,000 square feet of commercial space and 60 affordable housing units, including 20 owner-occupied units. By the time of the project's completion in 2001, however, Davenport Commons represented a different vision. Instead of being a university enclave in the city, Davenport Commons incorporated the wishes and needs of community members. The university presence was reduced to 610 beds in 125 units, all 60 of the residences were owner-occupied, and retail space had been increased to 2,100 square feet [6]. The original development layout had been altered to separate the student from non-student households. Students were now housed in taller structures on the north side of the parcel, and moderate-income ownership units along the southern side [7]. This re-arrangement was about more than differentiation, however: "the 50/50 split of the land was generally accepted and became highly symbolic for the community (Roxbury) as a way to reclaim the land for public benefit” ([8], p. 261). Additionally, the decision to focus exclusively on home ownership responded to the neighborhood's belief that ownership would provide residential stability in the area. The community's interest in reclamation and ownership stemmed from events that had taken place decades earlier, but were recalled with frustration and bitterness by longtime residents.

In the late 1960s, houses on four parcels between Columbus Avenue and Tremont Street, at the edge of the Roxbury section of Boston, were razed to make way for a new highway into the city that would be known as The Southwest Corridor. The Southwest Corridor project never materialized, and for several decades the lots were left vacant and were not returned to any constructive use. Through the mid-1990s, the parcels were in the care of the city's hybridized planning and development agency, the Boston Redevelopment Authority (BRA). The BRA had originally taken them by eminent domain for the highway project. By then, Boston who had experienced thirty years of population decline since World War II, was in the middle of its second decade of sustained growth. Population growth increased the pressure on Boston's already limited housing supply.

The 1990s also marked the rise of the knowledge economy, which enhanced the value of universities to the cities hosting them [9]. Northeastern University, which for many years had embodied a modest regional model, shifted its educational focus to that of a mainstream research 
university [6]. As Feldscher [10] points out, this switch to a mainstream research university changed the student profile more than the student enrollment. Northeastern had previously served local students who already lived and worked in or around the city and who might be interested in taking classes part-time or at night.

Largely because of a shift in focus, applications were arriving from all parts of the country from prospective students seeking to take advantage of the university's connection to a world-renowned educational center, as well as proximity to many of the city's most attractive neighborhoods. For many of these full-time undergraduate students (and their parents), on-campus housing was a necessity. As universities grow, however, housing availability quickly becomes a point of conflict between an institution, its neighborhood, and the wider municipality [11]. With the housing market tightening in one of the most thickly settled cities in the country, the BRA hoped to relieve the pressure through "the creation of more student housing and the development of more affordable housing” ([8], p. 254). Northeastern and the BRA began to discuss a combination of student housing and affordable housing on the vacant land between Columbus and Tremont, on Davenport Street.

However, as Calder, Grant and Muson point out, the nature of this partnership was very likely to incite controversy, no matter how well-intentioned: the scarcity of developable land in Boston ensures that any project of appreciable size will be politically sensitive. There is also a public perception in the area that many universities receive preferential treatment during the planning process. This suspicion was reinforced when a university official inadvertently disclosed the development plans at a community meeting. The accidental disclosure at the public meeting served as the public's first notification of the project, and came six months after project negotiations had begun [8].

To many residents of Roxbury, it appeared that the city government was clandestinely accommodating a prosperous neighbor's desire to acquire land that had once been theirs, so that college students could more comfortably live where they had been forced to vacate. The encroachment was bad enough, but the lack of public input was worse: "community members wanted a greater say in the process and a greater role in shaping change in their neighborhood” ([8], p. 258).

The development team's response to initial objections was crucial to the project overcoming an early miscalculation. The project had involved the creation of affordable housing units and retail space in addition to student housing, which was outside the realm of conventional dormitory construction. In recognition of these and other complexities, Northeastern sought out the expertise of developers and a community development corporation with familiarity with the management of affordable housing development projects. The partnership became known as the Madison Davenport Partners (MDP), and its constituent members had the capacity to build trust between the community and the university, and were local entities with an established presence in Roxbury. One of the partners, the Madison Park Development Corporation, was a fitting collaborator: it was founded in 1966 as the Lower Roxbury Community Corporation, when it secured a memorandum of understanding from the BRA to preserve housing in the neighborhood [12]. By creating this partnership, Northeastern granted MDP a level of decision-making authority that departed significantly from its established procedures.

Some in the Northeastern administration were displeased by the decision to cede control and form long-term partnerships with the MDP consortium. However, this meant that Northeastern did not have to face public opposition alone, or alongside bureaucrats. In the public meetings that followed the initial waves of disapproval and protest, individuals and groups were voicing their concerns to MDP 
personnel-individuals they had known and worked with for years. MDP's leadership included respected members of the Roxbury community [8], men and women unlikely to risk their reputations or jeopardize their long-term business and social interests. By reducing student density and increasing ownership, the development team was able to signal that all parties were interested in the long-term quality of life in Roxbury. In confirmation of the community's willingness to view the university as more of a partner than a powerhouse, MDP received nearly 700 applications for the new ownership units after the designs were finalized. In 2003, Davenport Commons received the Maxwell Award for excellence and innovation in the creation of affordable home ownership opportunities [13].

\section{New Haven: Yale and the Urban Resources Initiative}

Formed in 1989, the Urban Resources Initiative (URI) was the result of a partnership between the Yale School of Forestry and Environmental Studies; the City of Baltimore; and a local non-profit, the Parks and People Foundation. The Initiative sought "to develop research, education, and extension programs that link urban revitalization with environmental restoration” ([14], p. 264). The collaboration seemed to benefit all parties: the university would gain a platform to conduct social ecology and community forestry research in a large urban center, the city would be on the cutting edge of curriculum development and analysis, and the foundation would be able to advance its mission to promote civic engagement with urban open space in a high-profile manner. The Initiative's work drew the interest of other organizations in the area. By the mid-1990s, the URI also included researchers from the Institute of Ecosystem Studies, the University of Maryland: Baltimore County, the US Forest Service, and the US Geological Survey [14].

URI's success in Baltimore led some to believe that such a program could thrive in New Haven, CT-home of Yale University. New Haven, while smaller than Baltimore, shares some similarities: a port city contending with underperforming schools, pervasive poverty, and troublesome levels of violent crime. At the time, Yale was in the early stages of improving its relationship with the community by pivoting away from “business as usual.” In 1973, city officials refused the university's proposal to build two more colleges in the downtown [15] and one local developer speaking in 1989 characterized the university's actions during the 1970s with the following: "Yale did what Yale does best: retreat inside its walls and lock its doors” [16,17]. Making a break from this perceived pattern, Yale’s 1991 agreement with New Haven “marked a decisive turning point in the university' participation in civic affairs” ([16], p. 15). Among the developments was the formation of the New Haven Urban Resources Initiative (New Haven URI), which brought the research, education, and outreach techniques developed in Baltimore to the university's backyard, and the city's residents [18]. To ensure that the New Haven URI would serve the needs of both New Haven and Yale equally, the Initiative's Advisory Board legally separated from the university, incorporating as non-profit in 1991.

The program that came to New Haven was in a "beta" version, having already incorporated feedback from the experiences in Baltimore. While embracing a scope and mission statement similar to its predecessor in Baltimore, the New Haven URI took a different approach to environmental education, in concert with the city's schoolteachers. As Burch and Carrera noted, it incorporated "a more formal association with a public school program” ([18], p. 424). The most significant result of this curriculum-focused approach to environmental education was the development of the Open Spaces 
as Learning Places program, a progressive nine-week science curriculum for elementary and middle school students in New Haven public schools.

As stated by Fisman in her investigation into URI's effectiveness, the goal is "to have participants gain awareness of the ecological patterns and processes within their neighborhoods... starting with a focus close to school and expanding to the watershed scale” ([19], p. 40). Analyzing data gathered through a variety of means, Fisman's results "showed a significant positive effect of the program on students' awareness of the local environment and on their knowledge of environmental concepts” ([19], p. 39).

The program, taught by Yale students from 2001-2009, is not another example of a one-year intervention. The curriculum was developed with the city's teachers and administrators in order to conform to state-mandated science standards. As a testament to the program's success, the New Haven Board of Educators adopted the Open Spaces as Learning Places program into the required curriculum in 2009. That summer, "thirty New Haven teachers attended workshops sponsored by National Oceanic and Atmospheric Administration (NOAA) and prepared to lead the curriculum on their own" [20].

The New Haven URI serves both Yale and the New Haven community in its efforts to foster community-based land stewardship. In historically neglected areas of the city, residents often "are left with limited opportunities and are facing greater social isolation ([21], p. 20). Initiatives through the partnership enable faculty in the School of Forestry and Environmental Studies to examine the emerging field of urban ecology, in a manner that confers short-term and long-term environmental benefits to the community. Furthermore, the New Haven URI is able to advocate on behalf of the community to the indirect benefit of the university. In November 2013, the United Illuminating Company, the regional power supplier, responded to severe weather events in Connecticut with a plan to remove many street trees beneath power lines in the towns it serves. The New Haven URI responded in January 2014 with a formal position that emphasizes the social and environmental benefits of street trees, and calls for the implementation of various practices in the event of tree removal [22].

\section{Providence: Johnson and Wales and the Downcity Campus}

Like many of cities in New England, Providence, RI has long been associated with higher education. Johnson and Wales University (JWU) is one of five such institutions in the city, along with Brown University; Providence College; the Rhode Island School of Design (RISD); and Rhode Island College, the only public institution of the five. Though the schools provide the city with substantial esteem, employment, and energy, residents and city officials have long been frustrated with the impacts the institutions have had on civic life, and the heavy burden their tax-exempt status places on municipal operations.

In the late 1950s, community-led preservation and revitalization efforts organized around the once-vibrant College Hill neighborhood in response to the purchase-and-demolish expansion efforts of some of the schools. While it could be argued that the schools were merely following the city's blight-removal lead ([23], p. 140), the adversarial image of the university was pervasive: "as planner Lachlan F. Blair succinctly put it, 'Brown was the devil'” ([24], p. 160). While it is hard to imagine such an unseemly characterization being thrown about today, there is a growing concern that the universities are taking more money out of the city than they are putting back in. This belief was made plain by a 2009 proposal from the mayor's office to levy a tax of $\$ 150$ per semester on students 
enrolled in some of Providence's universities, in order to reduce a municipal budget deficit [25]. Due to Providence's key role in every aspect of the state's functioning, it is understandable that the city could use the help.

Along with serving as its capital, Providence is Rhode Island's economic engine, transportation hub, research lab, population center, and cultural exchange. Its 178,000 residents are enmeshed in a warren of streets and neighborhoods that has not grown beyond 19 square miles in its nearly 370 years, and real estate has long been at a premium. In such a small space, then, the number and variety of non-profit or tax-exempt institutions has a significant effect on both the municipal tax base and on the city’s operating budget [23]. In fact, according to the City of Providence's Finance Department, the tax-exempt status of seven of these institutions deprives the city of $\$ 97$ million in tax revenue every year. On the other side of the ledger, however, eight of the city's ten largest non-municipal employers are tax-exempt medical or educational institutions, accounting for 9.6 and 7.9 percent of the jobs in Providence, respectively ([26], p. 86).

While relations have improved as Providence began to present itself as the Renaissance City, the relationship between the city and its two most prominent schools, RISD and Brown, continues to be complicated by long-standing issues pertaining to growth, power, and trust. At the same time, Johnson and Wales has raised its profile in the city, embracing a different educational model in a different part of the downtown. Originally founded as a business school, JWU has long depended on the educational value of internships and workplace experience to compliment course learning. The university's flagship campus is in the Downcity section of Providence, separated from College Hill by the Woonasquatucket River. From this central location among the centers of civic and financial activity, JWU has been able to participate in a variety of initiatives to strengthen its relationship to the city, region, and state. Two are discussed here.

In 2006, JWU became the new host institution of the Rhode Island Small Business Development Center (RISBDC). The RISBDC provides business consulting services and training workshops at little or no cost to small establishments and startups across the state. Established in 1983, the RISBDC was originally hosted by Bryant University at their campus in Smithfield, ten miles northwest of Providence. The move to JWU enabled the Center to locate its headquarters and its Providence Metro service center in a prominent location in the heart of the city's downtown-within walking distance of City Hall, the State House, and public transit. Part of the RISBDC's mission is to increase entrepreneurial access to capital, and JWU's location provides the Center with an improved platform for networking options.

In addition to hosting the RISBDC, JWU also provides the center with a direct annual contribution of at least $\$ 250,000$ [27]. This accounts for over 20 percent of the center's budget and is surpassed only by the federal funding from the U.S. Small Business Administration. The most distinctive contribution, however, is the faculty and student interaction with RISBDC clients. Faculty lead workshops and trainings, supervise students as they engage with marketing campaigns or website development, and work with RISBDC staff to match entrepreneur to opportunity. Since moving to the Downcity location in 2006, the Center's work with clients "has helped to create and retain over 5,000 jobs in Rhode Island," and in the 2011-2012 academic year alone, "students provided over 9,000 hours of assistance to clients, translating to savings of approximately \$360,000” ([28], pp. 14-15). 
In a separate partnership, the International Culinary Institute at JWU has been a part of an ongoing effort with the Rhode Island Department of Health to combat obesity in the state. In 2006, the Initiative for a Healthy Weight published a document identifying the possible partnerships between a variety of state, non-profit, and educational entities in Rhode Island that could work together to meet benchmarks for near-term, medium-term, and long-term goals related to "improving nutrition, increasing physical activity, and decreasing the prevalence of obesity” across the state ([29], p. i). JWU was seen as a crucial partner in achieving goals related to improving community access to healthy foods, including: connecting farmers to distributors, worksites, and individuals; demonstrating accessible and hands-on cooking and meal planning skills; and increasing the presence of healthy food options at restaurants and fast-food establishments. Four years later, in another Department of Health document, JWU was selected as a co-op partner for an initiative to establish healthy food preparation and implementation strategies for Rhode Island restaurateurs by 2015. Having established menu choices and alternatives, JWU students "provide additional training and technical assistance" to kitchen staff and stakeholders ([30], p. 9).

JWU's culinary partnerships have put the university at the center of a thriving food scene in Providence. In 2012, the city was named the nation's top destination for food by Travel and Leisure Magazine [31]. To capitalize on this development, JWU worked with the Initiative for a Competitive Inner City (ICIC) and Next Street Financial to establish the city as the center of a food cluster, able to capitalize on Rhode Island's extensive competitive advantage in the production and distribution of natural and organic foods [32].

\section{Worcester: Worcester Polytechnic Institute and Gateway Park}

To encourage participation in its Brownfields Economic Redevelopment Initiative, the United States Environmental Protection Agency (EPA) began funding pilot projects across the country in the fall of 1993 [33]. The EPA initiative defined a brownfield as "a site, or portion thereof, that has actual or perceived contamination and an active potential for redevelopment or reuse” ([34], p. 2). As Dennison [33] outlines, the purpose of the initiative was not to mitigate the contamination of the brownfields themselves, but to assist communities in assembling a site inventory and generating creative approaches to cleanup and redevelopment.

The City of Worcester, Massachusetts was among the EPA's initial selections for pilot project funding, with good reason. Many of Worcester's manufacturing interests had moved away or closed their doors in the latter half of the 20th century and industrial parcels made up much of the city's vacant land. The initial inventory documented more than 200 brownfield sites in Worcester, contaminating so much ground that there were fewer than 100 developable acres left in a city of 37 square miles [35]. One of the first partnerships formed in Worcester in the wake of the EPA's "creative approach” initiative was the University Park Partnership.

Established in 1995 by Clark University and the Main South Community Development Corporation, the University Park Partnership was designed to lead neighborhood revitalization initiatives in the residential areas near Clark’s campus. The ongoing success of the UPP, along with the lasting impact of the Massachusetts Biotechnology Research Park, encouraged the Worcester Business Development Corporation (WBDC) and Worcester Polytechnic Institute (WPI) to form Gateway Park, LLC. 
Gateway Park, LLC had a common goal to bring mixed-use redevelopment options to an underused, stigmatized, but highly visible industrial area, and position it as the economic core of a larger district. The partnership's focus was an area between WPI's campus to the west, Interstate 290 to the east, and Route 9 to the south.

The Gateway Park Master Plan, drawn up by the partnership in advance of the acquisition process, envisioned a bioscience industry cluster as the cornerstone of the entire redevelopment program. Targeting 11 acres adjacent to an I-290 off ramp to Route 9, the partnership planned the construction of five buildings, totaling approximately 565,000 square feet [36]. The first phase of development would remediate the entire site, demolish unusable structures, construct a tax-exempt life sciences facility for WPI, provide sufficient parking for a full build-out scenario, and prepare four additional "pad-ready" sites for eventual construction and leasing. In order to generate property tax revenue for the city, the additional buildings were to be financed, developed, built, and owned by private developers outside of the Gateway Park partnership [37]. If the venture was successful, WPI would raise its bioengineering profile by working with the companies involved in Gateway Park, expand and upgrade its research facilities, and strengthen its ties to Worcester's downtown. Similarly, Worcester would benefit from development of long unused land, make successful use of grant funding, and expand its tax base.

Complicating the acquisition process were century-old easements pertaining to "railroad spurs and rights-of-way...city drainage systems and culverts...[and] seven separate parcels and property owners" ([37], p. 2). Furthermore, high contamination levels required adjustments to the intended site layout. After acquiring the parcels in 2000, developers realized that the proposed design would require prohibitively expensive cleanup efforts on the most contaminated parcels. If the parking area were constructed there instead, cleanup thresholds could be met in a more cost-effective manner. The new parking area would require an adjustment to the site's zoning, and in a show of support, City Hall accommodated the request [37]. Remediation efforts were completed in March of 2006, supported by $\$ 700,000$ in direct cleanup loans from the Massachusetts Development Finance Agency and \$1.48 million from EPA Brownfields Revolving Loan Fund grants [35]. Later that year, Gateway Park received its first industry accolades: the 2006 James D.P. Farrell Brownfields Project of the Year Award, presented by the Environmental Business Council of New England [38].

Having prepared the site’s infrastructure, access, and parking with over $\$ 4$ million in federal funds and another \$2 million in state funds [35], Gateway Park LLC restored the one remaining industrial building on the property. The long, rectangular, high-windowed brick structure was incorporated it into the design of the park's flagship: the four-story, 124,600-square-foot Life Sciences and Bioengineering Center (LSBC). The historic building was originally constructed by one of the university's founders, but was renovated to supply the research labs with office, meeting, and retail space. These efforts to preserve a piece of the industrial past led to Gateway Park’s second award, the Silver Hammer Award, in December of 2006 [39]. The award, given by the Worcester Regional Chamber of Commerce, was presented jointly to WPI and the WBDC for their historic preservation efforts in the run-up to the center's opening in 2007.

In addition to housing, WPI's graduate research programs in a variety of biosciences, the LSBC was designed to lease office and research space to companies in similar biotech industries. One such arrangement, the MBI Incubator, has operated since 2007 in conjunction with the Massachusetts 
Biomedical Initiatives. The incubator provides laboratory access, shared equipment, and offices for biomedical start-ups. In selecting Gateway Park as the Region 1 winner of the 2007 Phoenix Award, given annually to development projects addressing environmental and community issues, the Phoenix Awards Institute noted the specific economic impact of the 300 new jobs provided by the LSBC in its first year of operation [37]. Shortly thereafter, in confirmation of the partnership's encouraging successes, the Economic Development Administration recognized Gateway Park with the FY 2007 EDA Excellence in Economic Development Award for Urban or Suburban Economic Development [40].

As Gateway Park received formal recognition from local, regional, national, and federal levels, many more organizations expressed an interest in participating in the park's development plans. Construction plans submitted by a local development firm for the park's second facility, the Gateway II Wet Lab Science Building, were finalized at the start of 2010. In February, the Massachusetts Life Sciences Center, a quasi-public state agency tasked with job creation in the life sciences, awarded the green-lighted project a \$6.6 million grant to outfit and equip onsite facilities intended for WPI's Biomanufacturing Education and Training Center (BETC), the MBI Incubator, and the Massachusetts Academy of Mathematics and Science [41]. One month later, in March of 2010, WPI acquired the WBDC's stake in Gateway Park, assuming full ownership of the land, the parking facility, and the LSBC [36].

An agency primarily concerned with business development, the WBDC viewed the decision of the development firm to invest \$25 million in Gateway Park for the construction of Gateway II as a sign that the initial "launch" phase was complete. According to the WBDC [36], the partnership had "resulted in an investment of more than \$80 million, including over \$15 million in state and Federal funds," and had achieved its objectives. At the time of the transition, the LSBC was fully occupied, and the vision for Gateway II as a workforce training center for the biosciences suggested close partnerships with industry leaders. Gateway Park's future seemed bright, and in recouping its initial investment, the WBDC would be able to fund other initiatives in Worcester, including the conversion of unused school buildings into mixed-income housing one block south of Gateway Park. The ongoing "Voke Lofts" project is currently renovating and upgrading the former site of Worcester Vocational High School, and the expectation is that by 2013 the efforts will have added 84 one- or two-bedroom apartments to the downtown's limited housing stock [42].

Gateway Park has been an unqualified success. The redevelopment of the project area was no simple task, and it required the partners to take significant risks while delaying gratification. Careful planning at the outset enabled the partners to establish common ground, describe shared visions, consider alternative options, and build trust before testing the market. The nature of the partnership-a tax-exempt educational organization working in concert with a municipal development agency to foster the development of a high-skill, high-wage industry in a growing city-enabled it to leverage municipal, academic, and industry networks for project support at crucial points in the redevelopment process. A “big tent” by design, the Gateway Park project brought many different interests together, as part of something positive. And of all the interests under the tent, none seems to have fared better than the City of Worcester: tax base up, employment up, and brownfield inventory down. In a city with 28.9 percent of its property filed as tax-exempt, that is very welcome news [43]. 


\section{Conclusions}

The four partnerships included in this paper share two important characteristics: first, they operate in municipalities with exceptionally high levels of non-profit activity; second, they include third parties in the partnership. Where the non-profit sector is strong, universities need to be particularly creative in partnering to find ways to benefit the community, and third-party partnerships can be very helpful in that regard. We hold that while this third-party approach requires universities to cede some autonomy in the decision-making process, it increases the likelihood that a partnership will succeed.

In the case of New Haven URI, the organization itself became the third party, enabling it to carry out its mission for the community in a space between the university and the city. Gateway Park LLC served a similar function, as a nonprofit development agency and a private university formed a separate entity that was able to do business with the city to bring mixed-use development to a remediated brownfield site. For Johnson and Wales, the decision to emerge as a key component in a regional food cluster required JWU to seek outside input from competitive advantage researchers, to create a roadmap that includes the assets other local universities provide. Packaging and Industrial Design programs at the Rhode Island School of Design, for instance, would have a valuable role to play in the cluster's emergence [32].

Contrast these approaches with the experience at Davenport Commons. While the final product represented community-supported affordable housing elements and expanded commercial real estate, the university's initial approach did not include a third party. Rather, the university communicated with the city through the Boston Redevelopment Authority, which neighborhood residents held in exceptionally low regard. It was not until the public discovered the plans for Davenport Commons and voiced their opposition that Northeastern sought out local development guidance. It was the inclusion of the third party that made the difference.

Why might a tripartite arrangement for university-community partnerships improve the odds of success? Reviewing the eight core characteristics of partnerships that Maurrasse describes, the third-party system favorably affects three of them: partnerships are often "messy"; partnerships do not always select the right problems to address; and existing societal power dynamics continue to play out in partnerships [4]. In these instances, the university-community partnership at Davenport Commons was strengthened by the inclusion of the Madison Davenport Partners. MDP was able to help with the "messy" nature of public opposition; it was able to address the issues correctly, determining that a 60-unit development of affordable, owner-occupied housing was vastly preferable to a similar arrangement in which only 20 units would be owner-occupied; and it was able to navigate the power imbalance that residents felt, providing the community with an opportunity to plan with the city and the university, and not be planned for by the city and the university.

\section{Author Contributions}

All authors contributed equally to the research on this paper. Dr. Mullin and Dr. Kotval were primarily responsible for the writing of this paper, while Mr. Cooper and Dr. Kotval-K took on editing responsibilities. 


\section{Conflicts of Interest}

The authors declare no conflict of interest.

\section{References}

1. Cisneros, Henry. The University and the Urban Challenge. Washington, DC: U.S. Department of Housing and Urban Development, 1995.

2. The Office of University Partnerships, U.S. Department of Housing and Urban Development. “OUP Grants.” 2013. http://www.huduser.org/portal/oup/grants.html.

3. Kenyon, Daphne A., and Adam H. Langley. Payments in Lieu of Taxes: Balancing Municipal and Nonprofit Interests (Policy Focus Report). Cambridge, MA: Lincoln Institute of Land Policy, 2010.

4. Maurrasse, David J. Strategic Public Private Partnerships. Cheltenham, UK: Edward Elgar, 2013.

5. National Association of College and University Business Officers and Commonfund Institute. "U.S. and Canadian Institutions Listed by Fiscal Year 2012 Endowment Market Value and Percentage Change in Endowment Market Value from FY 2011 to FY 2012.” http://www.nacubo.org/Documents/research/2012NCSEPublicTablesEndowmentMarketValuesRe visedFebruary42013.pdf.

6. Sungu-Eryilmaz, Yesim. Town-Gown Collaboration in Land Use and Development (Policy Focus Report). Cambridge, MA: Lincoln Institute of Land Policy, 2009.

7. “Davenport Commons Housing-Boston, MA.” DHK Architects, 7 September 2012. http://www.dhkinc.com/Housing/affordable/9703.asp.

8. Calder, Allegra, Gabriel Grant, and Holly Hart Muson. "No Such Thing as Vacant Land: Northeastern University and Davenport Commons.” In The University as Urban Developer: Case Studies and Analysis (Cities and Contemporary Society). Edited by David C. Perry and Wim Wiewel. Armonk, NY: M. E. Sharpe, 2005, pp. 253-67.

9. Organisation for Economic Co-operation and Development. Higher Education and Regions: Globally Competitive, Regionally Engaged. Paris: OECD/IMHE, 2007.

10. Feldscher, Karen. Northeastern University, 1989-1996: The Curry Years, Smaller But Better. Boston: Northeastern UP, 2000.

11. Smith, Darren P. “Studentification: The Gentrification Factory?" In Urban Colonialism: Gentrification in a Global Context. Edited by Rowland Atkinson and Gary Bridge. London: Routledge, 2004, pp. 72-90

12. Corkery, Paul J. "BRA and Roxbury Citizen Group Reach Urban Renewal Agreement.” The Harvard Crimson, 6 January 1967. http://www.thecrimson.com/article/1967/1/6/bra-and-roxburycitizen-group-reach/.

13. Bookman, Joel D. "Leadership Strategies to Capture Emerging Markets." http://www. instituteccd.org/uploads/iccd/documents/emerging_markets.pdf.

14. Grove, Morgan J., and William R. Burch, Jr. "A social ecology approach and applications of urban ecosystem and landscape analyses: A case study of Baltimore, Maryland.” Urban Ecosystems 1 (1997): 259-75.

15. Rae, Douglas W. City: Urbanism and its End. New Haven, CT: Yale UP, 2003. 
16. Kodrzycki, Yolanda, and Ana Patricia Munoz. "Lessons from Resurgent Cities.” 2009 Annual Report, Federal Reserve Bank of Boston, Boston, 2009, pp. 9-31.

17. Mufson, Steven. "Focusing on Private Redevelopment, Not Public Urban Renewal.” Washington Post, 29 October 1989. http://www.highbeam.com/doc/1P2-1220102.html.

18. Burch, William R., Jr., and Jacqueline M. Carrera. "Out the Door and Down the Street: Enhancing Play, Community, and Work Environments as If Adulthood Mattered.” In Understanding Urban Ecosystems: A New Frontier for Science and Education. Edited by Alan R. Berkowitz, Charles H. Nilon and Karen S. Hollweg. New York: Springer-Verlag, 2003, pp. 417-29.

19. Fisman, Lianne. "The Effects of Local Learning on Environmental Awareness in Children: An Empirical Investigation.” The Journal of Environmental Education 36, no. 3 (2005): 39-50.

20. New Haven Urban Resources Initiative. “Open Spaces as Learning Places.” Yale School of Forestry \& Environmental Studies, 8 August 2012. http://environment.yale.edu/uri/ programs/other-programs/.

21. Maurrasse, David J. Beyond the Campus. New York: Routledge, 2001.

22. New Haven Urban Resources Initiative. "Programs.” Yale School of Forestry \& Environmental Studies, 10 February 2014. http://environment.yale.edu/uri/.

23. Gast, Frances M. “A Half-Century of Planning on College Hill: Institutional Growth, Historic Preservation, and the College Hill Study.” Planning for Higher Education 39, no. 3 (2011): 139-48.

24. Bunnell, Gene. "Providence, Rhode Island: A City Reconnects with its Past and Finds its Future." In Making Places Special. Chicago: Planners Press, 2002, pp. 152-211.

25. Schachter, Ron. "PILOTS Taking Off." University Business, January 2011. http://www.universitybusiness.com/article/pilots-taking.

26. Finance Department, City of Providence, Rhode Island. "Comprehensive Annual Financial Report, Fiscal Year Ended 30 June 2011.” http://www.providenceri.com/efile/1880.

27. Rhode Island Small Business Development Center. “2011 Annual Report.” https://www.risbdc.org/DocumentMaster.aspx?doc=1506.

28. RISBJ. “RI Small Business Development Center.” Rhode Island Small Business Journal 1, no. 5 (2012): 14-15.

29. Rhode Island Department of Health. Rhode Island's Plan for Healthy Eating and Active Living, 2006-2012. Providence, RI: Rhode Island Department of Health, 2006.

30. Rhode Island Department of Health. Eat Smart, Move More Rhode Island: A Plan for Action 2010-2015. Providence, RI: Rhode Island Department of Health, 2010.

31. Runey, Mim L. "Food Clusters Sparking Urban Growth and Economy Activity.” The Providence Journal, 1 December 2013. http://www.providencejournal.com/opinion/commentary/20131201mim-runey-food-clusters-sparking-urban-growth-and-economy-activity.ece.

32. Hull, Brian. “Providence’s Urban Food Ecosystem.” ICIC (Institute for a Competitive Inner City), 5 December 2013. http://www.icic.org/connection/blog-entry/blog-providences-urban-foodecosystem.

33. Dennison, Mark S. Brownfields Redevelopment: Programs and Strategies for Rehabilitating Contaminated Real Estate. Rockville, MD: Government Institutes, 1998.

34. Environmental Protection Agency. "National Brownfields Assessment Pilot: Worcester, MA.” EPA Report 500-F-97-041, May 1997. 
35. Environmental Protection Agency. "Brownfields Success Story. Worcester, Massachusetts: Gateway Park.” EPA Report 560-F-09-023, February 2009. http://www.epa.gov/brownfields/ success/worcester_ma_gateway_park_ss.pdf.

36. Worcester Business Development Corporation. “Gateway Park.” WBDC Projects, 18 September 2012. http://www.thewbdc.com/files/gateway.pdf.

37. Phoenix Awards Institute. "Gateway Park, Worcester, MA: 2007 Region 1 Winner.” 20 September 2012. http://www.phoenixawards.org/factsheets/2007_Region_1_Gateway_Park.pdf.

38. Environmental Business Council of New England. "2006 EBEE Awards Recipients.” Environmental Business Council of New England, 14 September 2012. http://www.ebcne.org/ index.php?id=188.

39. "WPI and WBDC to Receive Silver Hammer Award for Restoration of Historic Industrial Building in Gateway Park.” PR Newswire, 8 December 2006. http://www.prnewswire.com/newsreleases/wpi-and-wbdc-to-receive-silver-hammer-award-for-restoration-of-historic-industrialbuilding-in-gateway-park-56057447.html.

40. Erulkar, Benjamin. "Statement to U.S. Senate Committee on Environment and Public Works." http://www.commerce.gov/sites/default/files/documents/2013/january/erulkar0909.pdf.

41. Monahan, John J. “Biotech Lab Gets \$6.6M Grant.” Worcester Telegram \& Gazette, 25 February 2010. http://www.telegram.com/apps/pbcs.dll/section?Category=archive_search.

42. Mitra, Shuchi. “Gateway Park sees hope in Voke Lofts.” Worcester Magazine, 12 July 2012. http://worcestermag.com/2012/07/12/gateway-park-sees-hope-in-voke-lofts-162129485/9734.

43. Gutc, Jacquelyn. “Report: Tax-Exempt Property Up in Worcester.” Worcester Business Journal, 6 August 2013. http://www.wbjournal.com/article/20130806/NEWS01/130809961/report-taxexempt-property-up-in-worcester.

(C) 2014 by the authors; licensee MDPI, Basel, Switzerland. This article is an open access article distributed under the terms and conditions of the Creative Commons Attribution license (http://creativecommons.org/licenses/by/3.0/). 